\author{
ORNL-3448 \\ UC-25 - Metals, Ceramics, and Materials \\ TID-4500 (20th ed.)
}

\title{
EQUIPMENT FOR HARDNESS TESTING AT
}

\section{ELEVATED TEMPERATURES}

George Hallerman

R. J. Gray

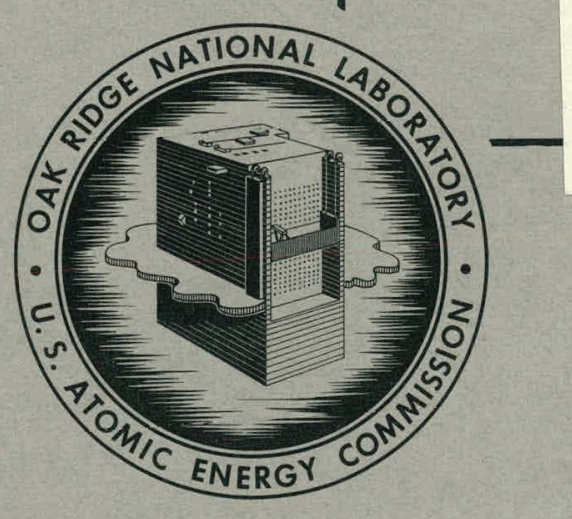

OAK RIDGE NATIONAL LABORATORY

operated by

UNION CARBIDE CORPORATION

for the

U.S. ATOMIC ENERGY COMMISSION 


\section{DISCLAIMER}

This report was prepared as an account of work sponsored by an agency of the United States Government. Neither the United States Government nor any agency Thereof, nor any of their employees, makes any warranty, express or implied, or assumes any legal liability or responsibility for the accuracy, completeness, or usefulness of any information, apparatus, product, or process disclosed, or represents that its use would not infringe privately owned rights. Reference herein to any specific commercial product, process, or service by trade name, trademark, manufacturer, or otherwise does not necessarily constitute or imply its endorsement, recommendation, or favoring by the United States Government or any agency thereof. The views and opinions of authors expressed herein do not necessarily state or reflect those of the United States Government or any agency thereof. 


\section{DISCLAIMER}

Portions of this document may be illegible in electronic image products. Images are produced from the best available original document. 
This report was prepared as an account of Government sponsored work. Neither the United States, nor the Commission, nor any person acting on behalf of the Commission:

A. Makes any warranty or representation, expressed or implied, with respect to the accuracy, completeness, or usefulness of the information contained in this report, or that the use of any information, apparatus, method, or process disclosed in this report may not infringe privately owned rights; or

B. Assumes any liabilities with respect to the use of, or for damages resulting from the use of any information, apparatus, method, or process disclosed in this report.

As used in the above, "person acting on behalf of the Commission" includes any employee or contractor of the Commission, or employee of such contractor, to the extent that such employee or contractor of the Commission, or employee of such contractor prepares, disseminates, or provides access to, any information pursuant to his employment or contract with the Commission, or his employment with such contractor. 
Contract No. W-7405-eng-26

Mctals and Ceramics Division

EQUIPMENT FOR HARDNESS TESTING AT ELEVATED TEMPERATURES

George Hallerman and R. J. Gray

DATE ISSUED

\section{dUL 319963}

OAK RIDGE NATIONAL LABORATORY

Oak Ridge, Tennessee operated by

UNION CARBIDE CORPORATION

for the

U. S. ATOMIC ENERGY COMMISSION 
EQUIPMENT FOR HARDNESS TESTING AT ELEVATED TTEMPERATURES

George Hallerman and R. J. Gray

ABSTRACT

The design and testing procedures of two elevated-temperature hardness testers developed at the Oak Ridge National Laboratory are described. One device uses a Rockwell tester with a large vertical capacity and a load range of 15 to $150 \mathrm{~kg}$. The tester is equipped with a $900^{\circ} \mathrm{C}$ heating chamber which maintains an argon atmosphere over the specimen and can be laterally displaced by a cross-feed mechanism to allow repeated hardness readings to be made on the same specimen. The second instrument is a microindentation hardness tester for hardness determinations to a maximum temperature of $1000^{\circ} \mathrm{C}$ in vacuum of $10^{-4}$ to $10^{-5}$ torr. A deadweight loading system with a 136-deg diamond pyramid (Vickers) indenter, capable of delivering static loads between 0.150 and $3 \mathrm{~kg}$, is contained within the vacuum chamber to avoid calibration probleins that arise when loads are applied from outside the vacuum system. The microindentation hardness tester allows up to 100 determinations to be made on a single specimen without opening the test chamber.

The applicability of the testers is illustrated by elevated-temperature hardness measurements on several commercial alloys, a group of niobium-vanadium alloys, and by the changes in hardness necurring at the transformation temperaturce of Armco Ingot iron and SAE No. 1020 steel. Hardness values of Haynes alloy No. 25 were determined at the temperatures of aging and are shown to be different from those obtained with the customary method of investigating age hardening. The testing is currently being used to aid and accelerate the development of alloys with desirable high-temperature properties.

\section{INTRODUCTION}

Indentation hardness is not a basic physical or mechanical property of a metal or an alloy but a characteristic quality that combines a rumber of these properties in a complex manner. In spite of the complexity of properties involved, indentation hardness testing at room temperature is an accepted industrial measurement and is frequently employed as a tool in scientific investigations because it is simple, inexpensive, 
and indicative of changes in properties of materials. Although the test involves a complex set of stress conditions, the indentation hardness is a measure of resistance of a material to deformation and, from this characteristic alone, many mechanical and physical properties of metals and alloys are estimated.

Elevated-temperature hardness is a measure of the high-temperature deformation characteristics of metals and alloys. A knowledge of the change in hardness with temperature of a metal can be used to circumvent the costly and time-consuming customary high-temperature strength determinations. Correlations have been found between elevated-temperature hardness and (a) the ultimate tensile strength of various steels at temperatures up to $1500^{\circ} \mathrm{C}^{1}$ (b) the tensile strength of iron, low carbon steel and cast iron, ${ }^{2}$ tungsten, tantalum, columbium, and their alloys, ${ }^{3}$ (c) the creep properties of a number of metals and alloys, ${ }^{14-7}$ (d) the elastic modulus of certain cubic metals, ${ }^{6}$ (e) the crystal structure and phase changes of cobalt, iron, titanium, uranium, and zirconium, ${ }^{8}$ and (f) the coefficient of thermal expansion for pure face-centered cubic and body-centered cubic metals. ${ }^{6}$ Russian workers ${ }^{9}$ have reported similar relationships.

IF. Garofalo, P. R. Malenock, and G. V. Smith, "Hardness of Various Steels at Elevated Temperatures," Trans. Am. Soc. Metals, 45: 377 (1953).

${ }^{2}$ E. R. Petty and H. O'Neill, "The Hardness of Iron, Low-Carbon Steels, and Cast Iron Roll Materials at Various Temperatures," J. Iron Steel .Inst., (London), 197: 141 (Feb. 1961).

${ }^{3}$ C. R. McKinsey et al., Investigation of Tungsten-Tantalum-ColumbiumBase Alloys, ASD Technical Report 61-3 (July 1961).

${ }^{4}$ T. O. Mulhearn and D. Tabor, "Creep and Hardness of Metals: A Physical Study," J. Inst. Metals, 89: 7 (1960-61).

${ }^{5}$ E. R. Petty, "Hardness and Other Physical Properties in Relation to Temperature," Metallurgia, 56: 231 (Nov. 1957).

${ }^{6}$ E. R. Petty and H. O'Neill, "Hot Hardness in Relation to the Physical Properties of Metals," Metallurgia, 63: 25 (Jan. 1961).

${ }^{7}$ E. E. Underwood, "Creep Properties from Short Time Tests," Materials \& Methods, p. 127 (April 1957).

${ }^{8} \mathrm{~W}$. Chubb, "Contribution of Crystal structure to the Hardness of Metal," J. Metals, 7(1) : 189 (Jan. 1955).

${ }^{9}$ M. G. Lozinskii, Visokotemperaturnaya Metallographia, Mashgiz, Moscow, 1956. (Translation: High Temperature Metallography, Pergamon Press, New York, Oxford, London, and Paris, 1961). 
Elevated-temperature hardness testing equipment was designed and constructed at the Oak Ridge National Laboratory (ORNL) to aid and accelerate the development of alloys with desirable high-temperature properties. The equipment consists of a Rockwell tester adapted for use at elevated temperatures and a microindentation hardness tester. The design of the microindentation hardness tester incorporates some features of testers described in the literature ${ }^{1,8-19}$ with a number of modifications conceived at ORNL.

\section{DESCRIPTION OF EQUIPPMENT}

\section{Rockwell Tester}

The major parts of the Rockwell hot hardness instrument are a 20-in. vertical capacity hardness tester with a dial gage to indicate Rockwell

${ }^{10} \mathrm{E}$. C. Bishop and M. Cohen, "Hardness Testing of High Speed Steel at High Temperatures," Metal Progr., 43: 413 (1943).

${ }^{11_{F}}$. P. Bens, "Hardness Testing of Metals and Alloys at Elevated Temperature," Trans. Am. Soc. Metals, 38: 505 (1947).

${ }^{12}$ P. S. Bergh, High Temperature Micro-Hardness Tester, Technical Report No. M-5, Silver Spring Laboratory, The Kellex Corp. (Dec. 23, 1948).

$13 \mathrm{~J}$. H. Westbrook, "Microhardness Testing at High Temperatures," Am. Soc. T'esting Mater. Proc., 57: 873 (1957).

${ }^{14} \mathrm{~J} . \mathrm{H}$. Westbrook, "An Iüproved Microhardness Tester for HighTemperature Use," ASTM Bulletin No. 246, p 53 (May 1960).

${ }^{15} \mathrm{~A}$. Brenner, "Microhardness Tester for Metals at Elevated Temperatures," Journal of Research of the National Bureau of Standards, 46(2), Research Paper 2185 (Feb. 1951).

${ }^{16} \mathrm{M}$. Semchyshen and C. S. Torgerson, "Apparatus for Determining the Hardness of Metals at Temperatures up to $3000^{\circ} \mathrm{F}$, "Trans. Am. Soc. Metals, 50: 830 (1958).

${ }^{17}$ L. M. Fitzgerald, "Measurement of Hardness at Very High Temperatures," Brit. J. Appl. Phys., 11: 551 (Dec. 1960).

${ }^{18}$. E. Phelps, "Hot Hardness Properties of Cobalt-Base Stellite Alloys," Metallurgia, 65: 229 (1962).

${ }^{19} \mathrm{G}$. H. Bannister, R. C. Burnett, and J. R. Murray, "Aging and Hot Hardness Characteristics of Certain Thorium Alloys," J. Nucl. Mater., 2(1): 51 (1960). 
standard or superficial readings and a heating chamber capable of reaching $900^{\circ} \mathrm{C}$. A view of the Rockwell hot hardness tester with the associated equipment and a schematic drawing of the heating chamber are shown in Figs. 1 and 2. The specimen and the hardness indenter are protected during heating by an argon environment.

The penetrator of the Rockwell tester is a 120-deg synthetic sapphire or diamond cone set in a molybdenum or Inconel mounting. The upper end of the Inconel plunger extension is water cooled and equipped with a deflector to protect the dial gage of the tester from excessive temperatures.

A Marshall Products Company heating chamber was modified with an $x-y$ positioner to allow accurate location of the penetrator above the specimen. All metal parts of the heating chamber interior exposed to high temperatures are made of stainless steel or Inconel. The furnace shell, base plate, and sealing plate are water cooled. The Alundum muffle of the furnace is wound with a nickel-chromium element and operated with a maximum input power of $1.5 \mathrm{kw}$ supplied from a Powerstat and a wheelco temperature controller. The temperature of the furnace is controlled by means of a Chromel-P-Alumel thermocouple located at the heating element. The specimen temperature is indicated by a second Chromel-P-Alumel thermocouple spot-welded to the underside of a l/16-in.-thick center part of the pedestal. The pedestal is separated from the water-cooled base plate by a I/8-in.-thick aluminum-oxide $\left(\mathrm{Al}_{2} \mathrm{O}_{3}\right)$ disk to decrease heat losses from the specimen. Argon gas is permitted to escape from the interior of the heating chamber through an O-ring seal on the top of the sealing plate. This is necessary because a tight-fitting seal would hamper the vertical motion of the plunger extension.

Repeated hardness determinations on the same specimen are made by means of horizontal displacement of the heating chamber on the table of. the hardness machine with the aid of the cross-feed screws of the $x-y$ positioner. Thus, a single specimen is often used to obtain an entire series of hardness impressions at temperatures from 25 to $900^{\circ} \mathrm{C}$, as opposed to customary elevated-temperature testing methods which frequently require numerous tests and relatively difficult-to-prepare specimens. Figure 3 shows a typical specimen with a series of indentations obtained at various temperatures. 


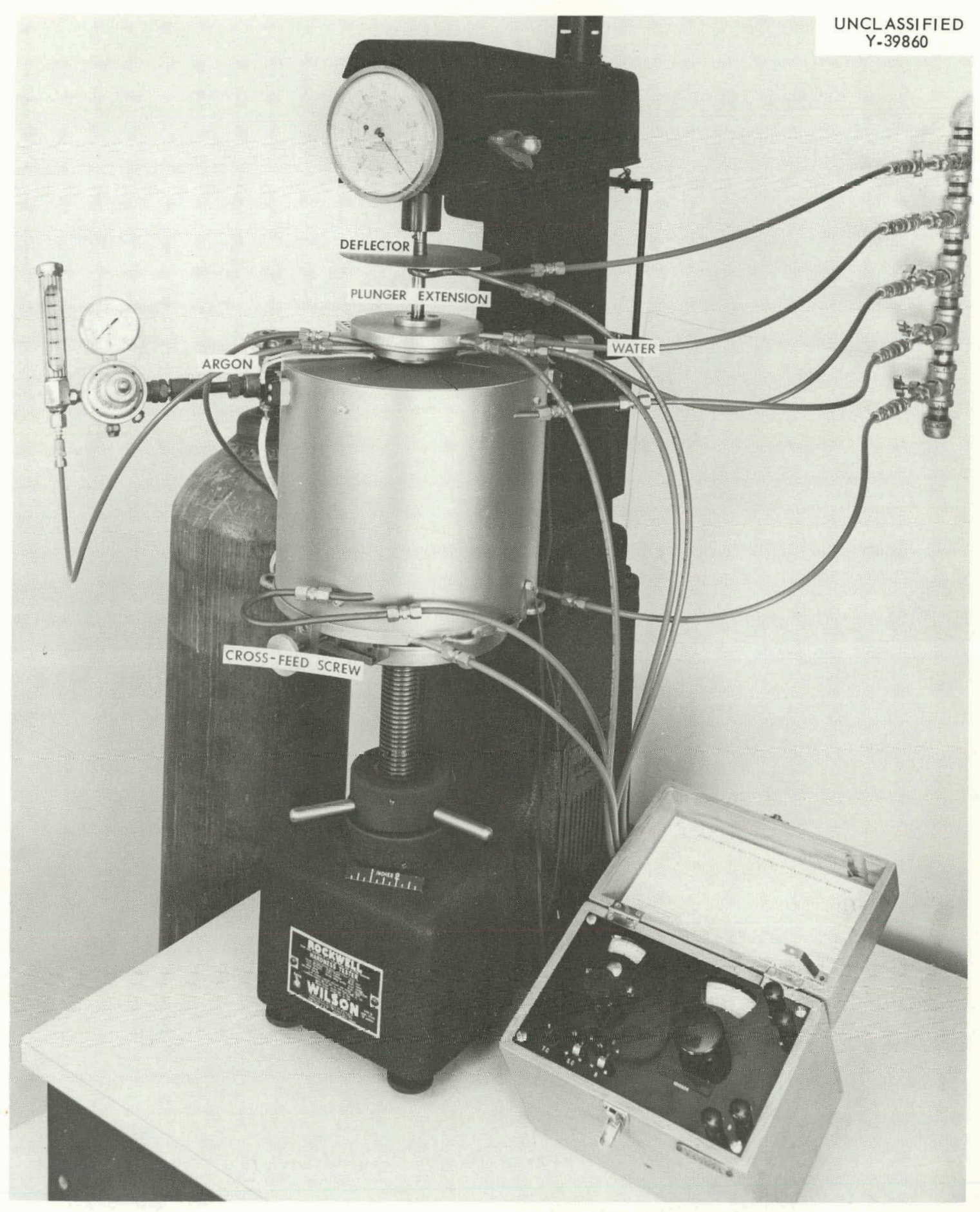

Fig. 1. Rockwcll Hardness Tester with a Heating Chamber to Allow Hardness Testing to $900^{\circ} \mathrm{C}$ in Argon Atmosphere. 


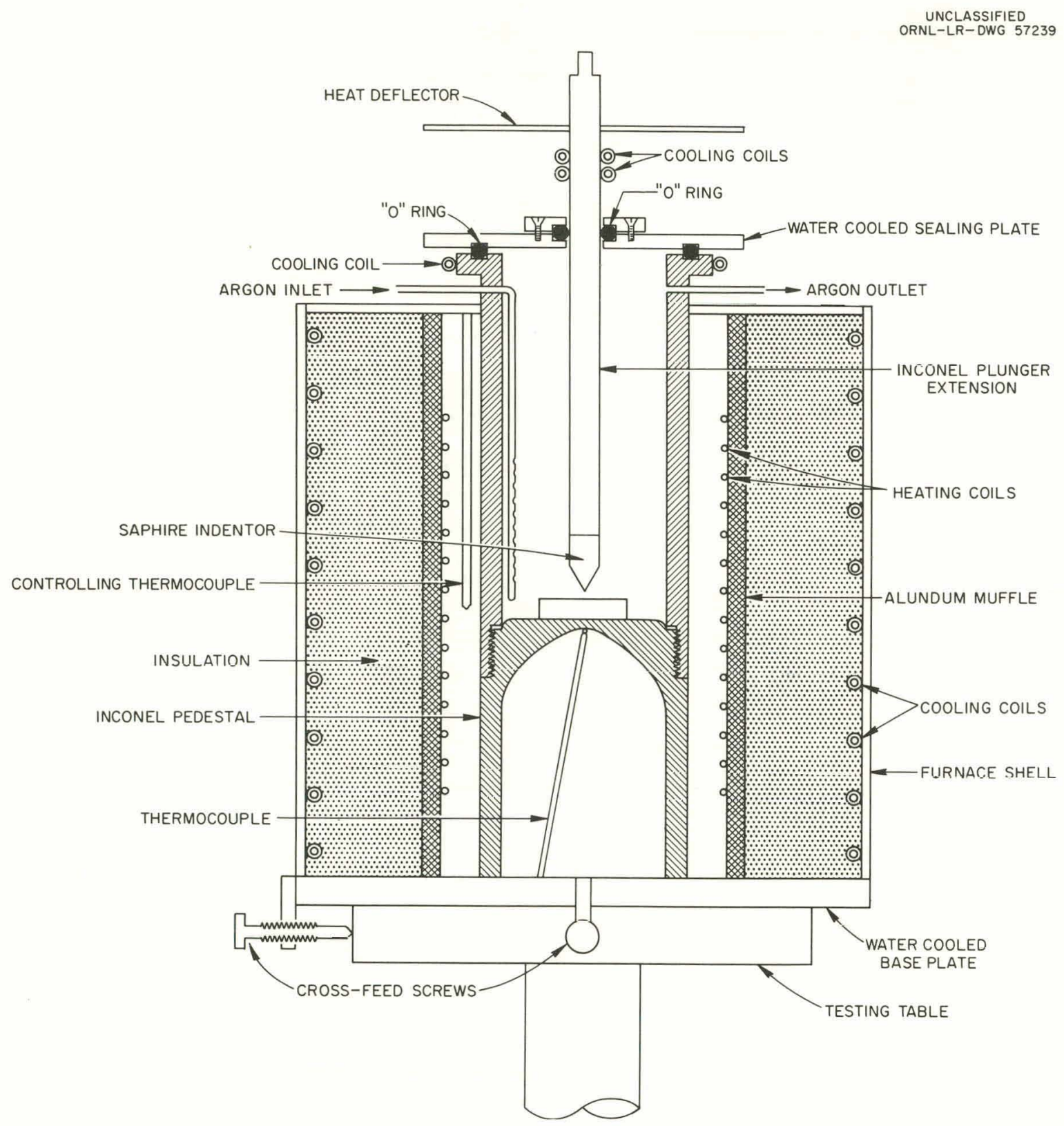

Fig. 2. Schematic Drawing of the Heating Chamber Used with Rockwell Tester. 


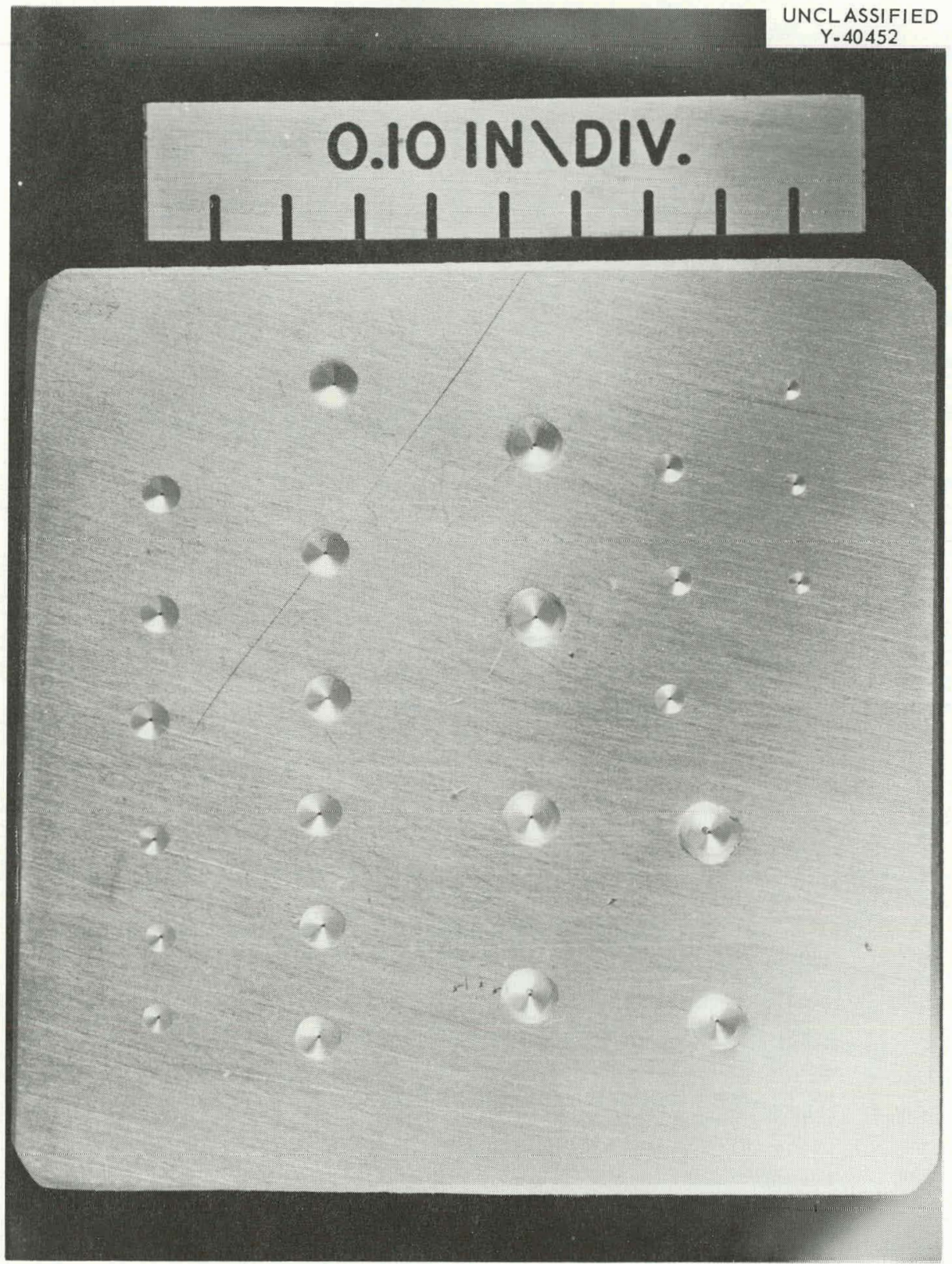

Fig. 3. Typical Hot Hardness Specimen. Indentations obtained at different temperatures with the Rockwell tester. 
Microindentation Hardness Tester

The microindentation hardness tester is self-contained, with the loading mechanism, indenter assembly, and furnace built as one compact unit. The schematic drawing of the tester and a photograph of the testing chamber are shown in Figs. 4 and 5. Auxiliary components, not shown, consist of a 4-in. oil diffusion pump vacuum system, a Powerstat and a Wheelco temperature controller, a potentiometer to measure the specimen temperature, and an inert-atmosphere supply tank. Although nearly all tests are performed in vacuum, it is possible to introduce an inert gas into the testing chamber.

The $\mathrm{Al}_{2} \mathrm{O}_{3}$ muffle of the furnace is wound internally with a Nichrome heating element. The furnace is surrounded by tantalum and stainless steel radiation shields. The upper and lower heater supports are made of stainless steel plates, flame sprayed with $\mathrm{Al}_{2} \mathrm{O}_{3}$ powder on the surfaces facing the heater. The bell jar and the base plate of the testing chamber are water cooled.

The temperature in the chamber is controlled by means of a Chromel-PAlumel thermocouple located near the furnace windings. The specimen temperature is measured by a similar thermocouple in contact with the specimen. Thermal contact between the specimen and the thermocouple is established by filling the space between the thermocouple bead and the walls of a predrilled hole in the center of the specimen with tantalum or platimum foils. Calibration tests have shown that the temperature variation between a thermocouple mounted this way and a thermocouple welded to the specimen surface is less than $2^{\circ} \mathrm{C}$ at temperatures up to $1000^{\circ} \mathrm{C}$.

In operation, the sample, which rests on the Inconel anvil, is raised by means of a micropositioner attached to the pedestal control. The stainless steel pushrod, which connects the micropositioner with the pushrod insulator and the anvil, enters the heating chamber through a water-cooled double o-ring seal. The pushrod is guided by a ball bushing which permits both axial and rotational motion of the rod. The coarse adjustment of the micropositioner is used to lift the specimen to a height 


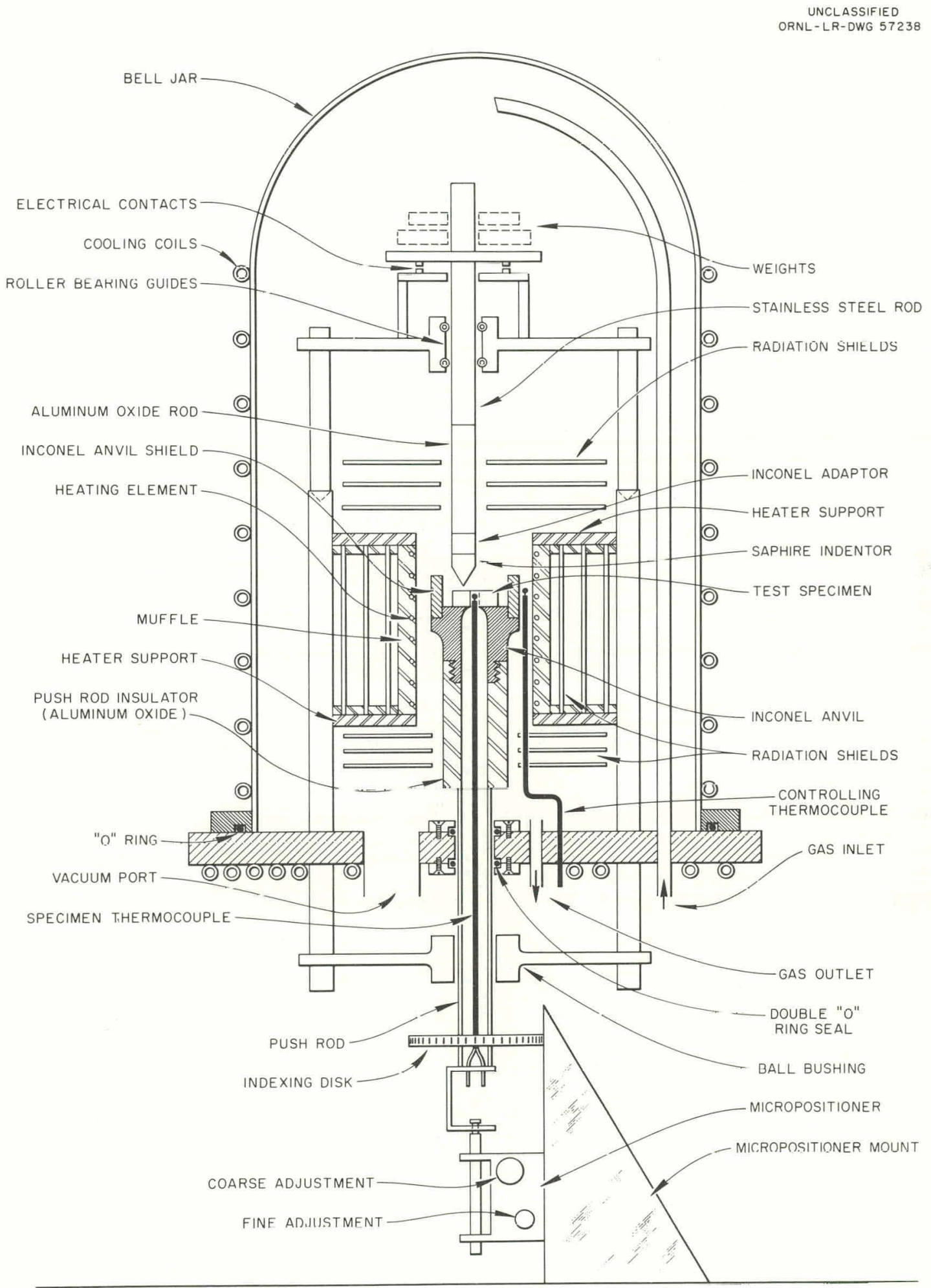

Fig. 4. Schematic Drawing of Elevated-Temperature Microindentation Hardness Tester. Hardness impressions are made in vacuum at temperatures up to $1000^{\circ} \mathrm{C}$. 


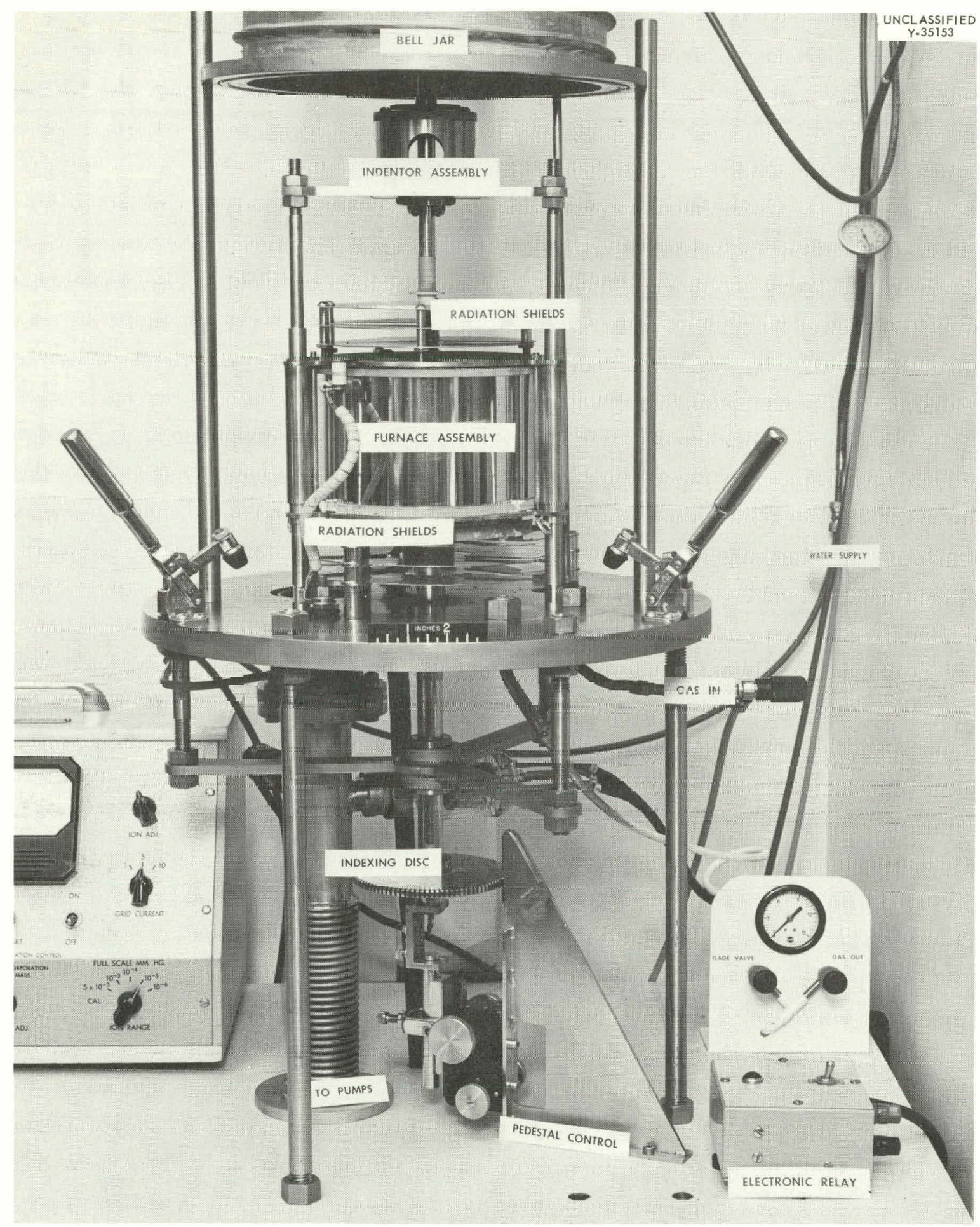

Fig. 5. Testing Chamber of the Elevated-Temperature Microindentation Hardness Tester with Bell Jar Raised. 
approximately $\mathrm{l} / \mathrm{l} 6 \mathrm{in}$. from the indenter tip. The fine adjustment knob is used to continue the upward motion of the specimen at an estimated rate of $1 \mathrm{~mm} / \mathrm{min}$; the slow motion is necessary if impact of the indenter on the specimen is to he avoided.

Figure 6 shows the indenter assembly. The indenter is screwed to a molybdenum or Inconel adapter which is connected to a threaded $\mathrm{Al}_{2} \mathrm{O}_{3}$ rod and a stainless steel rod - the latter supports the doughnut-shaped weights. The stainless steel rod is guided by six unlubricated roller bearings and is made to fit loosely between the guide to minimize friction. Weight calibrations made at room temperature have shown this design to result in negligible friction. It may be assumed that there is also no binding during testing at elevated temperatures; the temperature of the indenter housing and the indenter rod is below $200^{\circ} \mathrm{C}$ when the specimen is at $1000^{\circ} \mathrm{C}$.

During a hardness determination, the slowly rising specimen lifts the indenter, with the indenter rod and the weights, from three contact points on the top of the indenter housing. This opens the circuit of an electronic relay which is diagrammed in Fig. 7. To avoid arcing during operation, the relay is so designed that only a few microamperes pass through the contact points of the indenter assembly. The control lamp of the relay is actuated only when all three electrical contacts are open, indicating that the specimen supports the full indenter load. This permits the operator to control the exact time of full application of the load - a very important factor in hot hardness testing.

The vertical axis of the indenter is displaced from the center of the specimen by means of an adjustable slide in the housing of the indenter assembly (Fig. 6). The rotation of the indexing disk located on the pedestal pushrod (Figs. 4 and 5) allows up to 100 indentations to be made on a single specimen without the need for turning off the heating elements or breaking the vacuum. Figure 8 shows a hot hardness specimen with a circle of indentations obtained with this arrangement. The diameter of the circle is determined by the displacement of the indenter axis from the center of the specimen. The hole in the specimen accommodates the specimen thermocouple, as described above. 


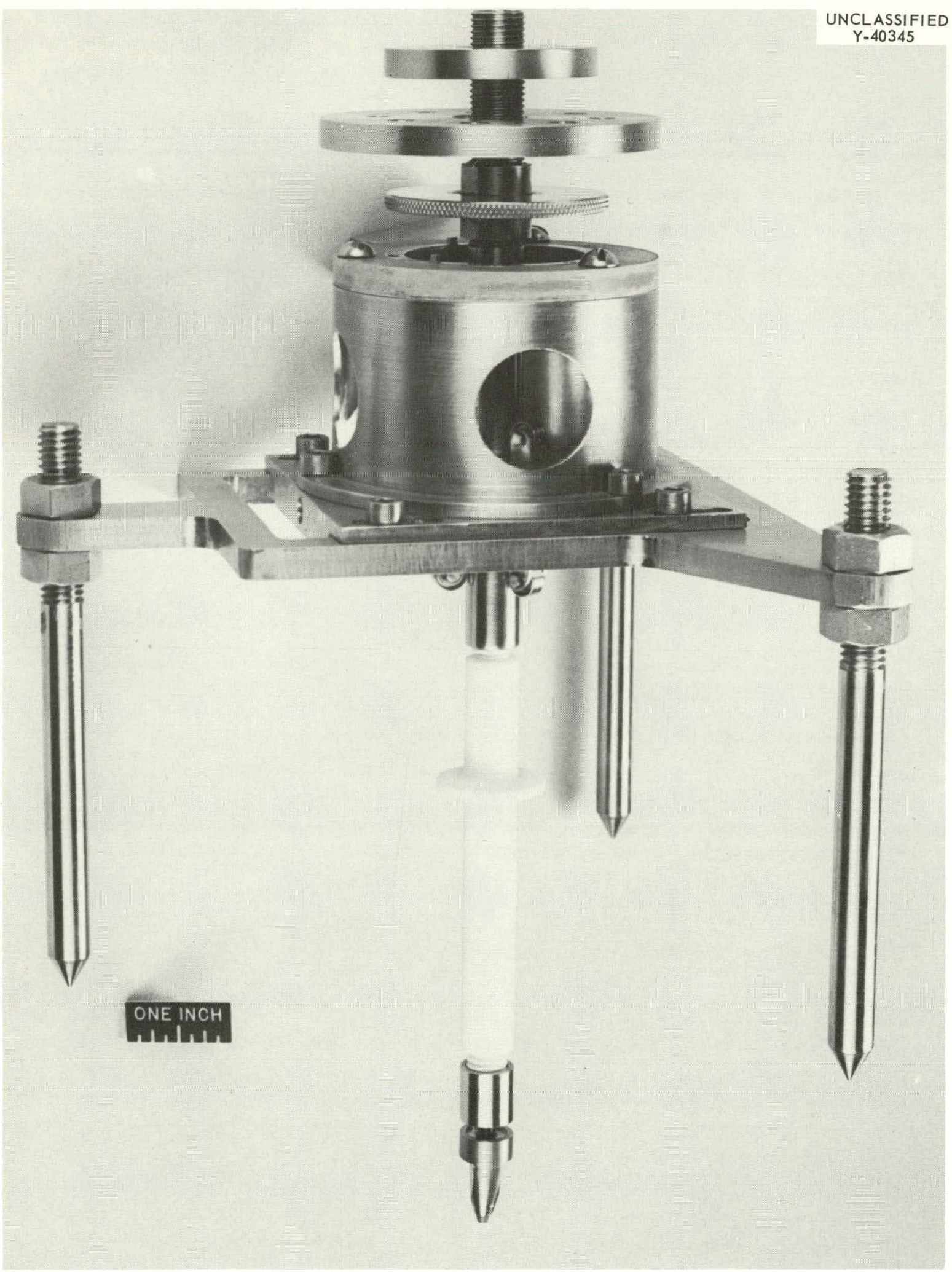

Fig. 6. Indenter Assembly. 
UNCLASSIFIED

ORNL-LR-DWG 57237

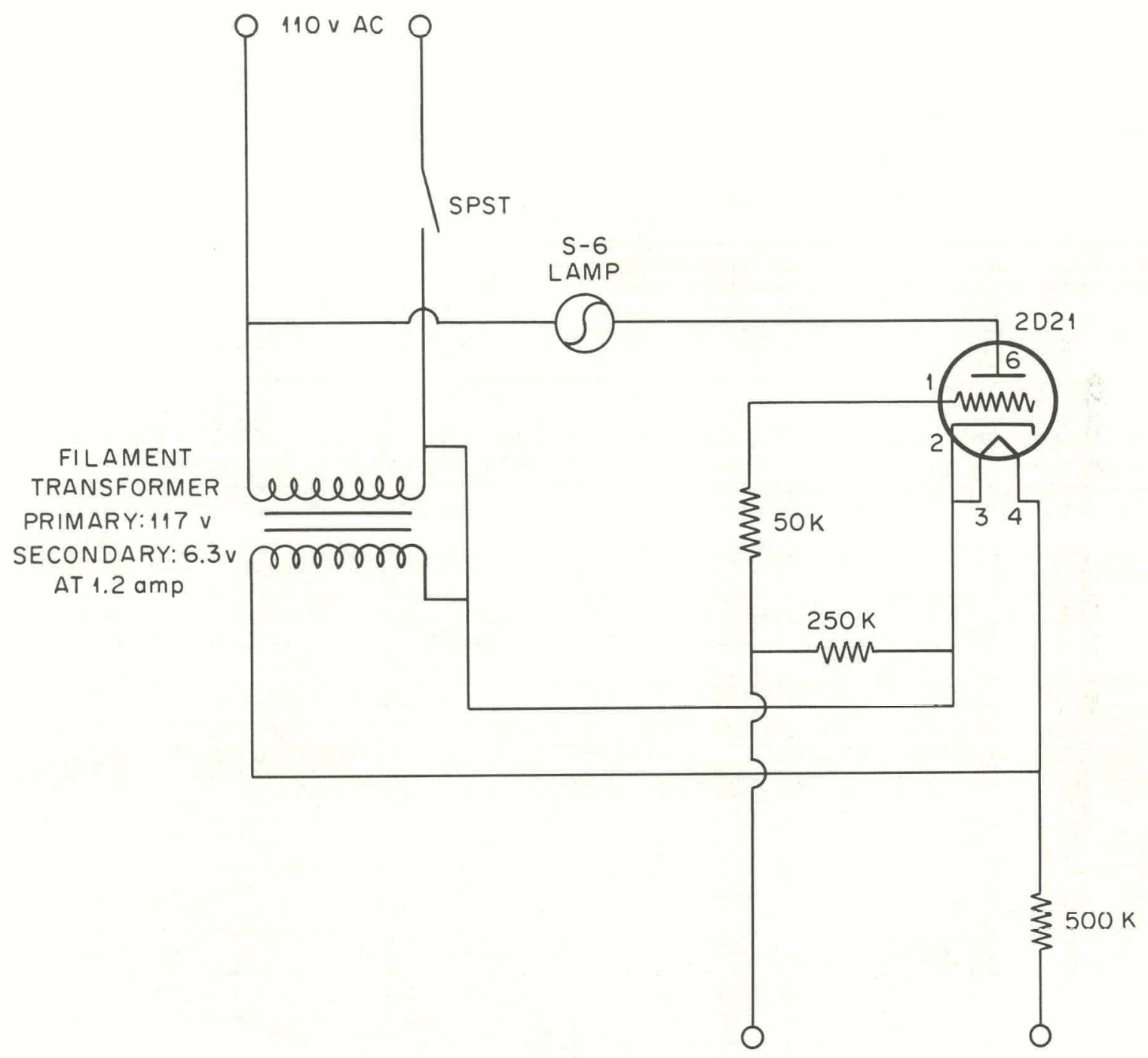

Fig. 7. Electronic Relay of the Indenter Assembly Used to Determine the Duration of Load Application. 


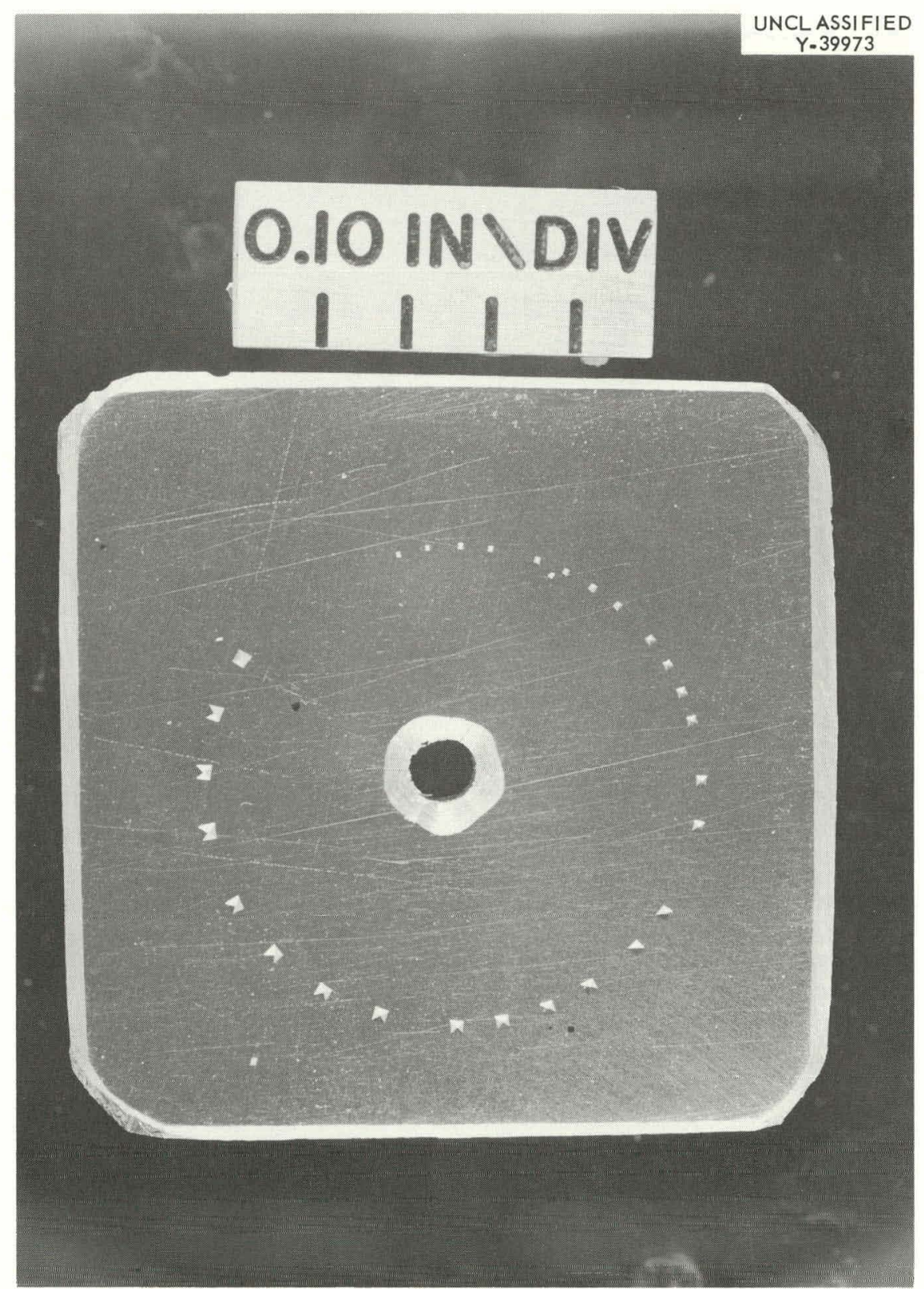

Fig. 8. Typical Hot Hardness Specimen. Indentations obtained at different temperatures with the microindentation hardness tester. 
The indenter is a synthetic sapphire Vickers-type 136-deg pyramid set in a molybdenum holder. Diamond, the conventional material for roomtemperature testing, has undesirable characteristics at elevated temperatures. Erosion of the diamond tip due to solution of carbon from the diamond at elevated temperatures has been reported on iron and low-carbon steel specimens, ${ }^{2}$ and on chromium-bearing alloys. ${ }^{1}$ Even at room temperature, adhesion of niobium, titanium, and zirconium has been reported. ${ }^{20}$ Synthetic sapphire, although softer than diamond, is a suitable material at temperatures at least up to $1000^{\circ} \mathrm{C}$. Figure 9 is a photomicrograph of a hardness indentation obtained at $1000^{\circ} \mathrm{C}$ on the surface of Haynes alloy No. 25 with a sapphire indenter and a 2-kg load. The edges of the indentation are smooth, showing no deterioration of the indenter, although it had been used in a number of previous hot hardness determinations. Molybdenum is used as the holder for the synthetic sapphire indenter because of the similar thermal expansion characteristics of the two materials.

The microindentation hardness tester operates at temperatures up to $1000^{\circ} \mathrm{C}$ in a vacuum of $10^{-4}$ to $10^{-5}$ torr. The load may be varied from $150 \mathrm{~g}$, the weight of the indenter and indenter rods alone, to $3 \mathrm{~kg}$ with addcd weights. The accuracy and sensitivity of this hardness tester at room temperature are the same as of a conventional room-temperature hardness tester.

\section{TESTING PROCEDURE}

Specimens used for hot hardness testing are usually 1 in. in diameter and $1 / 8$ to $1 / 4$ in. thick. The test surfaces of samples are gound and polished using standard metallographic techniques. Polishing is often performed on vibratory polishers, ${ }^{21}$ particularly when a large number of specimens are being processed. The results of hardness testing were found by Garofalo et al. ${ }^{1}$ to be dependent on the quality of specimen

${ }^{20} \mathrm{H}$. Abrecht, "Über das Haften von Niob, Titan und Zirkonium an Härteprüfdiamanten," Z. Metallk., 52: 836 (1961).

${ }^{2 I_{E}}$. I. Long, Jr., and R. J. Gray, "Better Metallographic Techniques ... Polishing by Vibration," Metal Progr., 74(4): 145 (1958). 


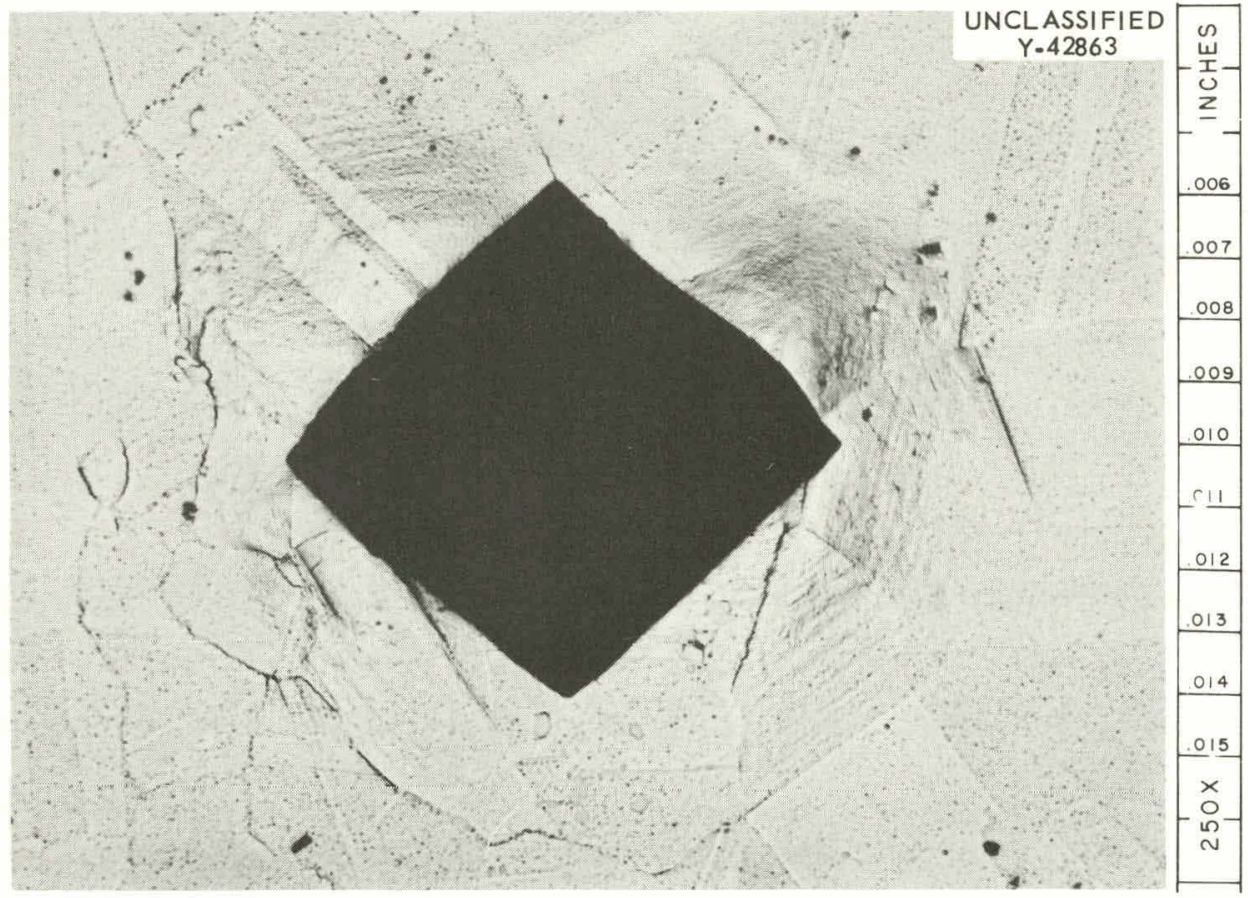

Fig. 9. Hardness Indentation on the Surface of Haynes Alloy No. 25 at $1000^{\circ} \mathrm{C}$. Synthetic sapphire indenter. 2-kg load, 15-sec load application. 
surface preparation. The vibratory polishing technique produces a specimen surface acceptable for hardness determinations as well as for metallographic examinations.

When the Rockwell hot hardness tester is to be used, the sealing plate on top of the heating chamber is raised and the test specimen is placed on the anvil. The test chamber is flushed with high-purity argon prior to testing; during the test the chamber is maintained at a slightly positive argon pressure. The specimen is heated to the desired temperatures and hardness determinations are made in the came manncr as with the conventional Rockwell hardness tester. Either standard (60-150 kg) or superficial loads $(15-45 \mathrm{~kg})$ may be used. Successive indentations are made after displacing the entire heating chamber with the aid of the cross-feed screws.

Before the elevated-temperature microindentation hardness tester is used, the indenter assembly and the upper radiation shields are removed. The polished specimen is then placed on the anvil and thin foils are pressed into the center hole of the specimen around the thermocouple bead. The radiation shields and the indenter assembly are replaced and suitable weights are placed in position. Prior to heating, the testing chamber is evacuated to a pressure of $10^{-4}$ torr or less. Although a number of ceramic parts are used in the chamber, outgassing presents no major problem; operating pressures are reached in about 15 min and, after completion of hot hardness tests, the surfaces of the specimens are not visibly oxidized.

The specimens can be heated and maintained at a desired temperature with the temperature controller. A minimum of three hardness indentations is then made prior to heating to the next temperature level. Since Westbrook ${ }^{13}$ obtained close agreement between isothermal hardness tests and tests made during continuous hcating at $5^{\circ} \mathrm{C} / \mathrm{min}$, in most hardness tests the specimens are heated continuously at rates not greater than $5^{\circ} \mathrm{C} / \mathrm{min}$ - usually about $4^{\circ} \mathrm{C} / \mathrm{min}$.

Each specimen is tested on a conventional hardness tester, both prior to actual hot hardness testing and after completion of the hot hardness run when the specimen has cooled to room temperature. The 
hardness values so obtained are then compared with the hardness determined with the hot hardness tester at room temperature, prior to and after completion of the tes.t. This procedure, used with both of the hot hardness testers, provides a check on the performance of the apparatus and on the condition of the indenter.

Uniformity in the time of load application is important in hot hardness testing. In all of the examples shown in this report, the full load was maintained for $15 \mathrm{sec}$. Hardness impressions made in microindentation testers at elevated temperatures are measured at room temperature. The correction for thermal contraction during cooling is insignificant and may be neglected for most investigations.

$$
\text { HOT HARDNESS RESULTS - ROCKWELL TTESTER }
$$

\section{Commercial Alloys}

A series of commercial alloys was investigated at elevated:temperatures to test the capability of the Rockwell tester. The nominal composition of these alloys, as well as other alloys tested, is given in Table 1. Average results of three háaness determinations of electrolytic copper, SAE No. 1020 steel, type 347 stainless steel, Inconel, Inconel.X, and INOR-8 alloys at elevated temperatures are shown in Fig $: 10$.

The effect of age hardening of Inconel $X$ is shown in Fig. 1l. The "as-received" curve is reproduced from Fig. 10. The "aged" curve was obtained from a second hot hardness mun on the same specimen aged by heating to $875^{\circ} \mathrm{C}$ while hardness determinations were made during the first mun. Figure 11 shows that up to $775^{\circ} \mathrm{C}$ the specimen increased in hardness due to aging and that at any testing temperature the aged Inconel $\mathrm{X}$ is harder than INOR-8 of Fig. 10. No aging effects were observed during the second hot hardness run on the INOR- 8 specimen.

\section{Aluminum}

In elevated-temperature hardness determinations on soft materials having hardness that decreases with temperature at a high rate, it is often convenient to report the depth of indentulions at elevated 
Table 1. Composition of Alloys Used in Hot Hardness Testing

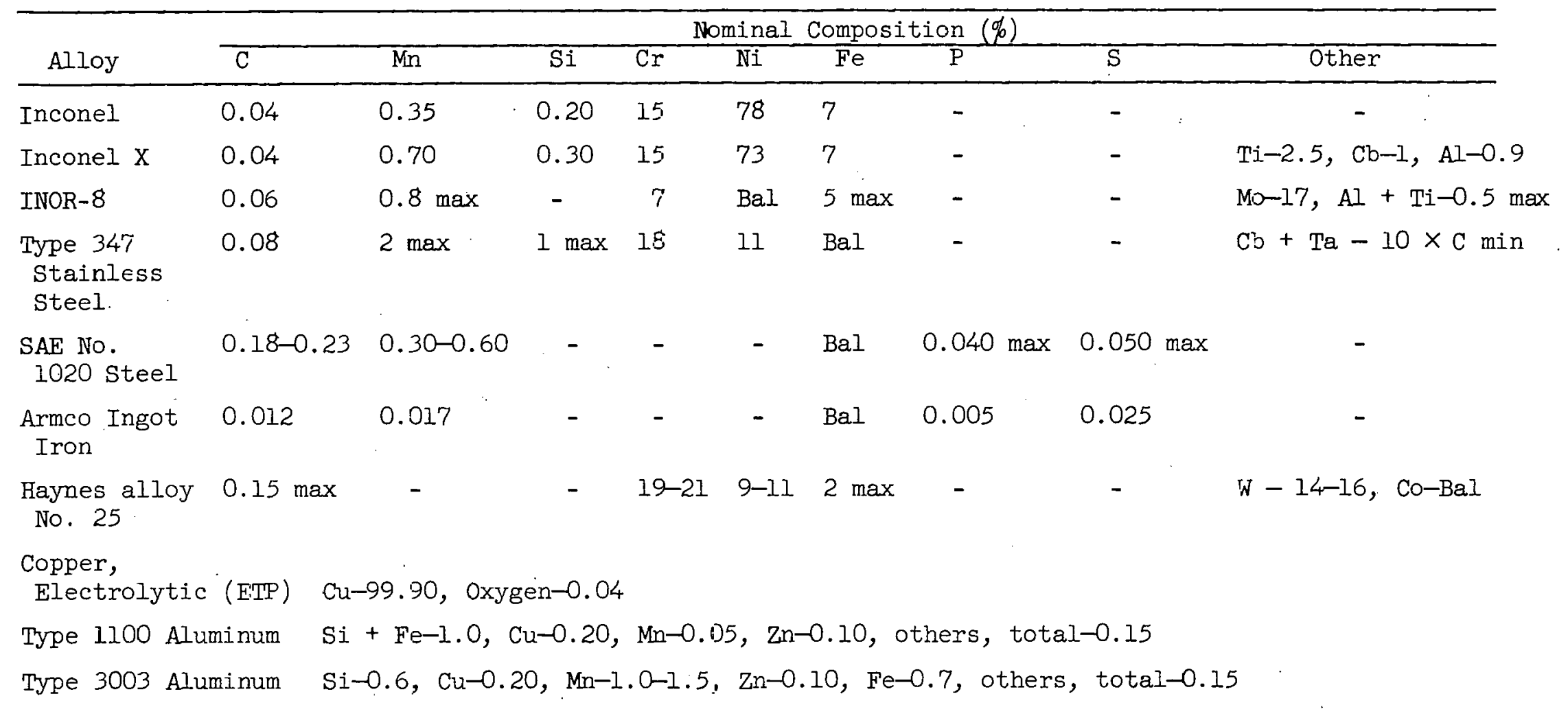


UNCLASSIFIED

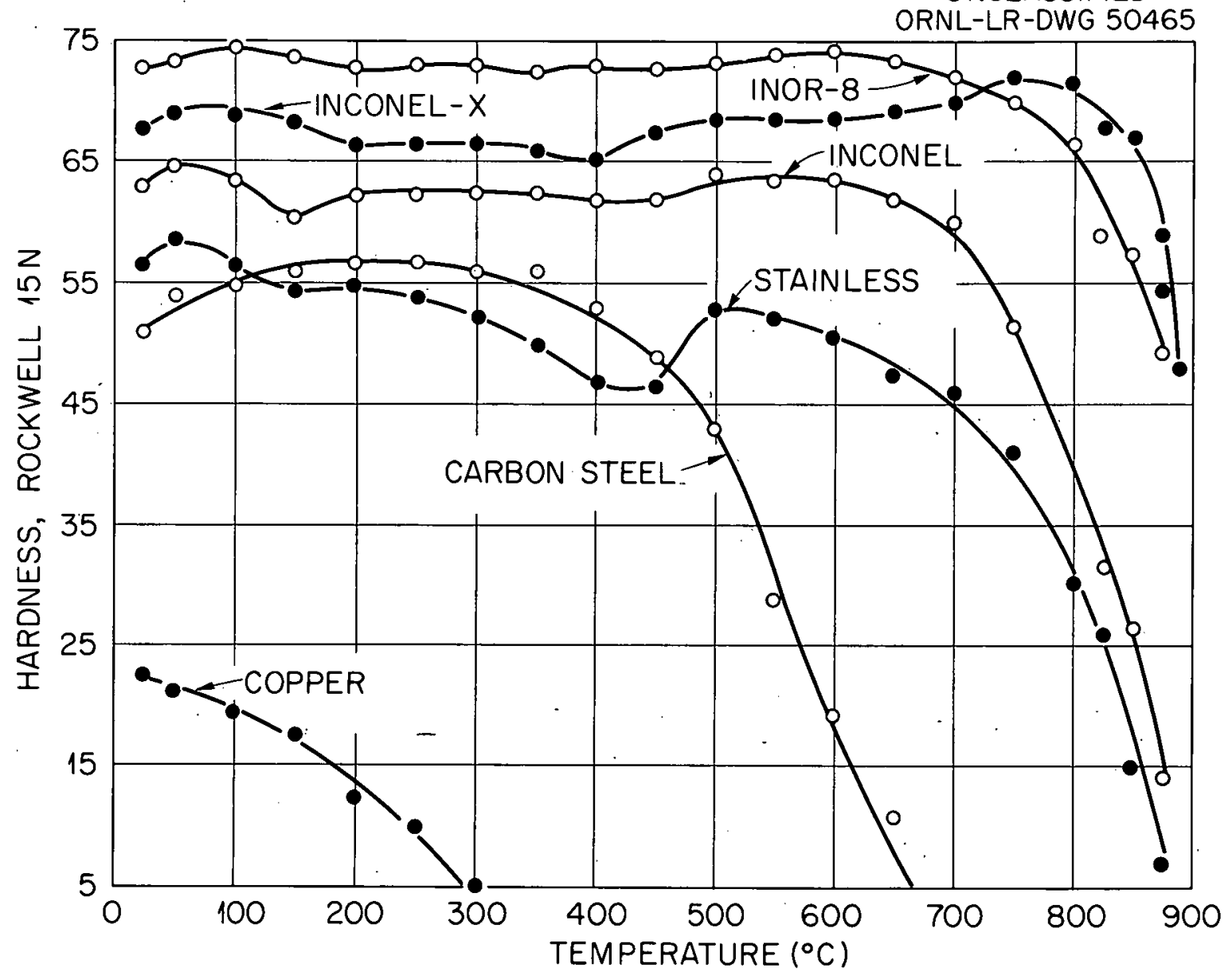

Fig. 10. Hardness of Commercial Metals and Alloys as a Function of Temperature. The steel specimens shown dre type 347 stainless steel and SAE No. 1020 steel, tested in the as-received condition. 
UNCLASSIFIED

ORNL-LR-DWG 50466

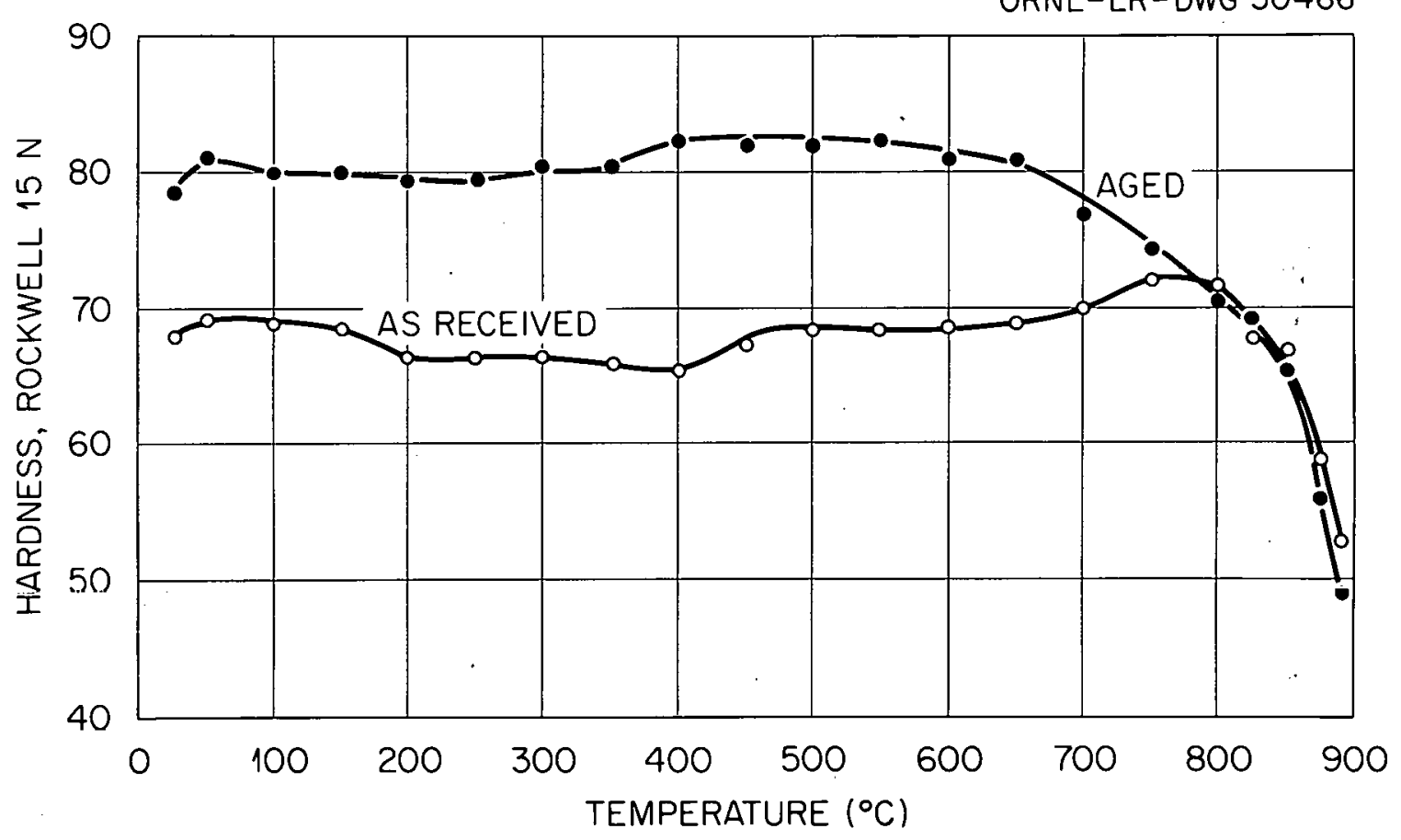

Fig. 11. Hardness of Inconel $\mathrm{X}$ as a Function of Temperature. 
temperatures to avoid the use of negative Rockwell hardness numbers. The value of the depth of indentation (in microns) on the Rockwell superficial scale is readily obtained 22 by subtracting the hardness reading from 100. Thus, for hardness readings of 20 and -60 , the respective values of the depth of indentation are 80 and $160 \mu$. Figure 12 shows the depth of indentation of a 1/8-in. carbide ball penetrator at 15 $\mathrm{kg}$ load as a function of temperature for two aluminum alloys. Type $3003^{\prime}$ aluminum alloy is harder than the type 1100 aluminum alloy up to $450^{\circ} \mathrm{C}$. Furthermore, the type 1100 alloy at room temperature is as hard as the type 3003 alloy at about $300^{\circ} \mathrm{C}$; at $350^{\circ} \mathrm{C}$ its hardness is the same as the hardness of the type 3003 alloy at about $450^{\circ} \mathrm{C}$.

HOT HARDINESS RESULTS - MICROINDENTATION HARDNESS TESTER

Phase Transformation of Iron and Steel

$\mathrm{Chubb}^{8}$ has shown, by measuring the hardness of metals at temperatures just above and just below their allotropic changes, that the crystal structure has a real effect upon the strength of metals. The sensitivity of the ORNL elevated-temperature microindentation hardness tester was demonstrated by sharp changes in hardness at the phase transformation temperature of iron. The transformation from the body-centered cubic to the face-centered cubic stmucture of Armco Ingot iron is manif'ested by a sharp increase in hardness (Fig. 13). Figure 13 also shows that SAE No. 1020 steel is harder than Armco iron in the $500-1000^{\circ} \mathrm{C}$ temperature range and that the transformation of the steel occurs at a lower and wider temperature range than does the transformation of Armco iron.

\section{Niobium-Vanadium Alloys}

The usefulness of the elevated-temperature microindentation hardness tester as a screening tool in alloy development is shown in the hot hardness survey of the niobium-vanadium alloys, particularly when the simplicity and costs of hot hardness determinations are compared with those of elevated-temperature tensile strength testing.

${ }^{22}$ V. E. Lysaght, Indentation Hardness Testing, p 103, Reinhold Publishing Corp., New York, 1949. 


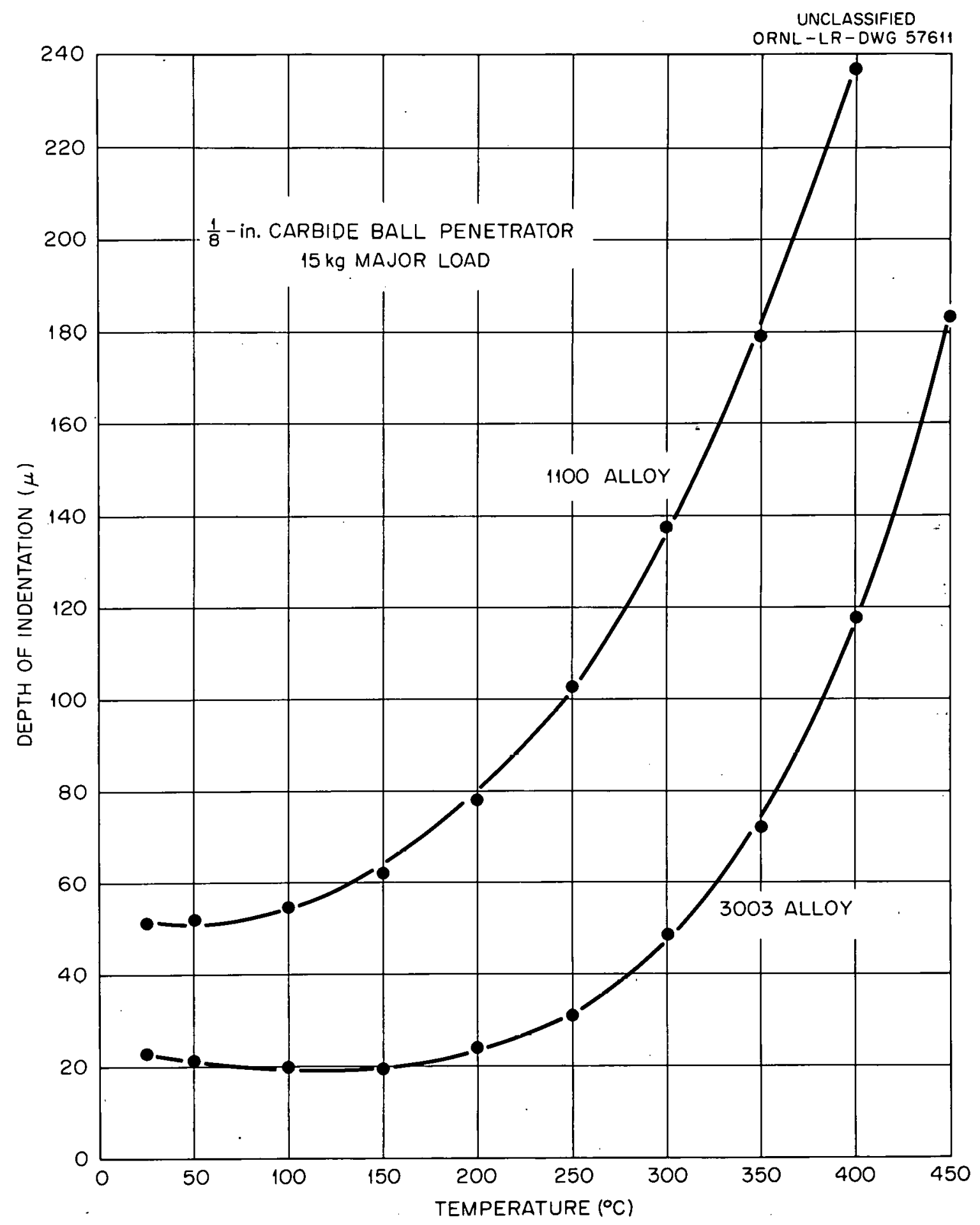

Fig. 12. Depth of Indentation of Types 1100 and 3003 Aluminum Alloys as a Function of Temperature. 


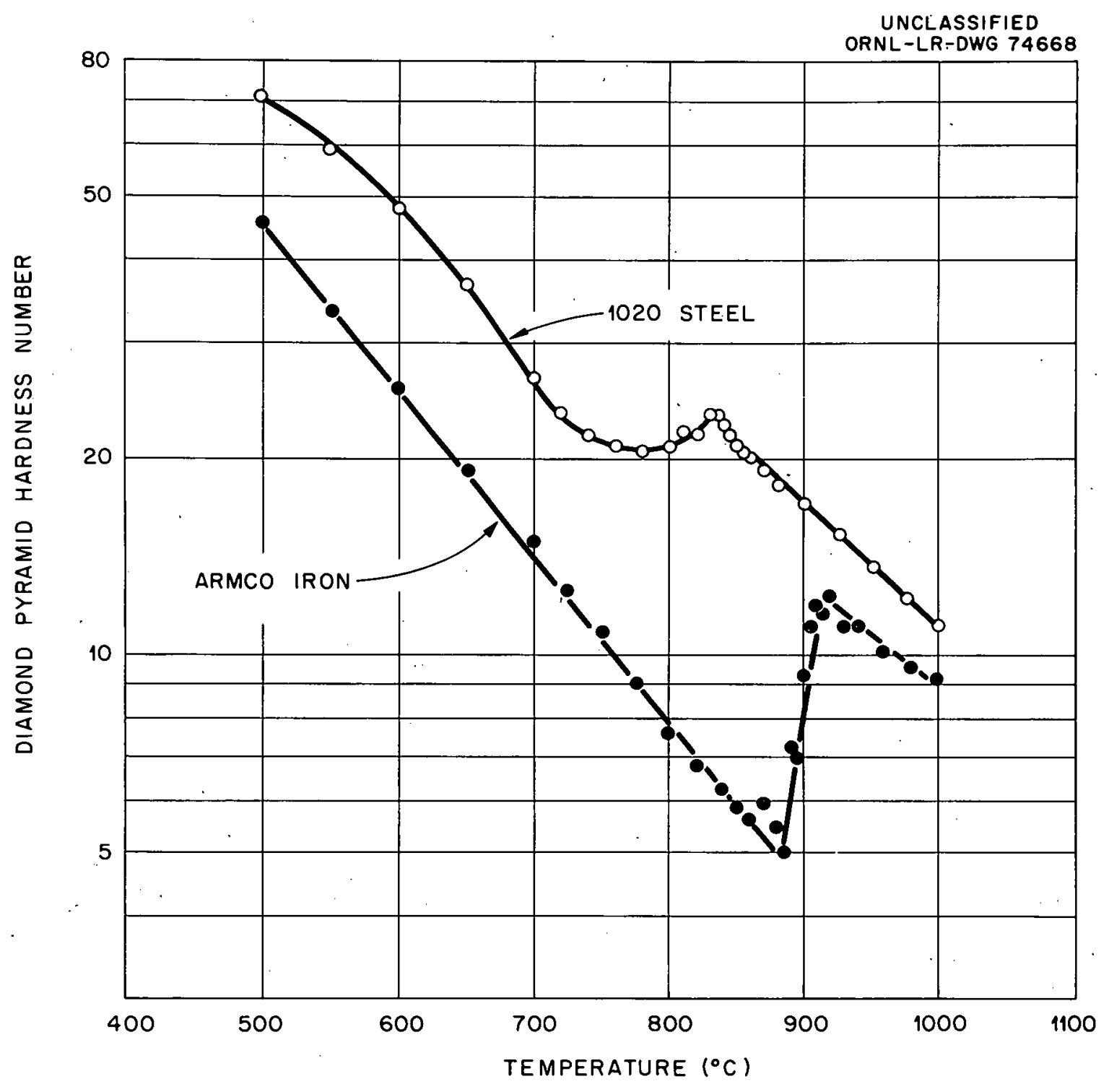

Fig. 13. Elevated-Temperature Hardness of Armco, Ingot Iron and SAE No. 1020 steel. 1-kg load. 
The niobium-vanadium alloys tested contained $1,10,20,30,50$, and 60 wt $\% \mathrm{~V}$. These alloys exhibit complete solid solubility. All specimens were given a prior heat treatment in vacuum for $2 \mathrm{hr}$ at $1200^{\circ} \mathrm{C}$. The results shown in Fig. 14 reveal that (a) the hardness decreases relatively little with increase in temperature for all compositions tested, (b) the hardness increases with increase in vanadium content in the entire temperature range for alloys containing up to $30 \% \mathrm{~V}$, and (c) at $1000^{\circ} \mathrm{C}$ the hardness of $\mathrm{Nb}-60 \% \mathrm{~V}$. alloy is the same as that of $\mathrm{Nb}-10 \% \mathrm{~V}$ and lower than the hardness of the alloys containing 20, 30, or $50 \% \mathrm{~V}$ (hardness vs composition curve - insert in Fig. 14).

These results are in good agreement with those obtained at Armour Research Foundation, 23 where it was found that the maximum strength occurred at about $\mathrm{Nb}-40 \% \mathrm{~V}$ when vanadium-niobium alloy series was tested for ultimate tensile strength at $2000^{\circ} \mathrm{F}\left(1093^{\circ} \mathrm{C}\right)$.

\section{Age Hardening of Haynes Alloy No. 25}

In the customary method of studying age hardening, the process of aging is intermpted by cooling the specimen and measuring its roomtemperature hardness. However, the aging process may be conveniently measured while it is occurring at an elevated temperature by a series of hardness measurements at suitable time intervals.

To evuluate the two methods of obtaining age-hardening data, 18 samples of Haynes alloy No. 25 were annealed for $2 \mathrm{hr}$ at $2250^{\circ} \mathrm{F}\left(1232^{\circ} \mathrm{C}\right)$. Three groups of five samples were considered necessary for the conventional age-hardening tests at 1400,1650 , and $1800^{\circ} \mathrm{F}(760,899$, and $\left.982^{\circ} \mathrm{C}\right)$. Individual samples were aged for 4, 16, 32, 64, and $100 \mathrm{hr}$ at the three temperatures, then water quenched. Room-temperature hardness as a function of aging time for these samples is show in the broken lines of Fig. 15. Only three samples were necessary for each of the three temperatures to determine the hardness of the alloy at the aging

${ }^{23}$ B. P. Rajala and R. J. VanThyne, Final Report - Improved VanadiumBase Alloys, ARF 2191-6 (Dec. 27, 1960). 


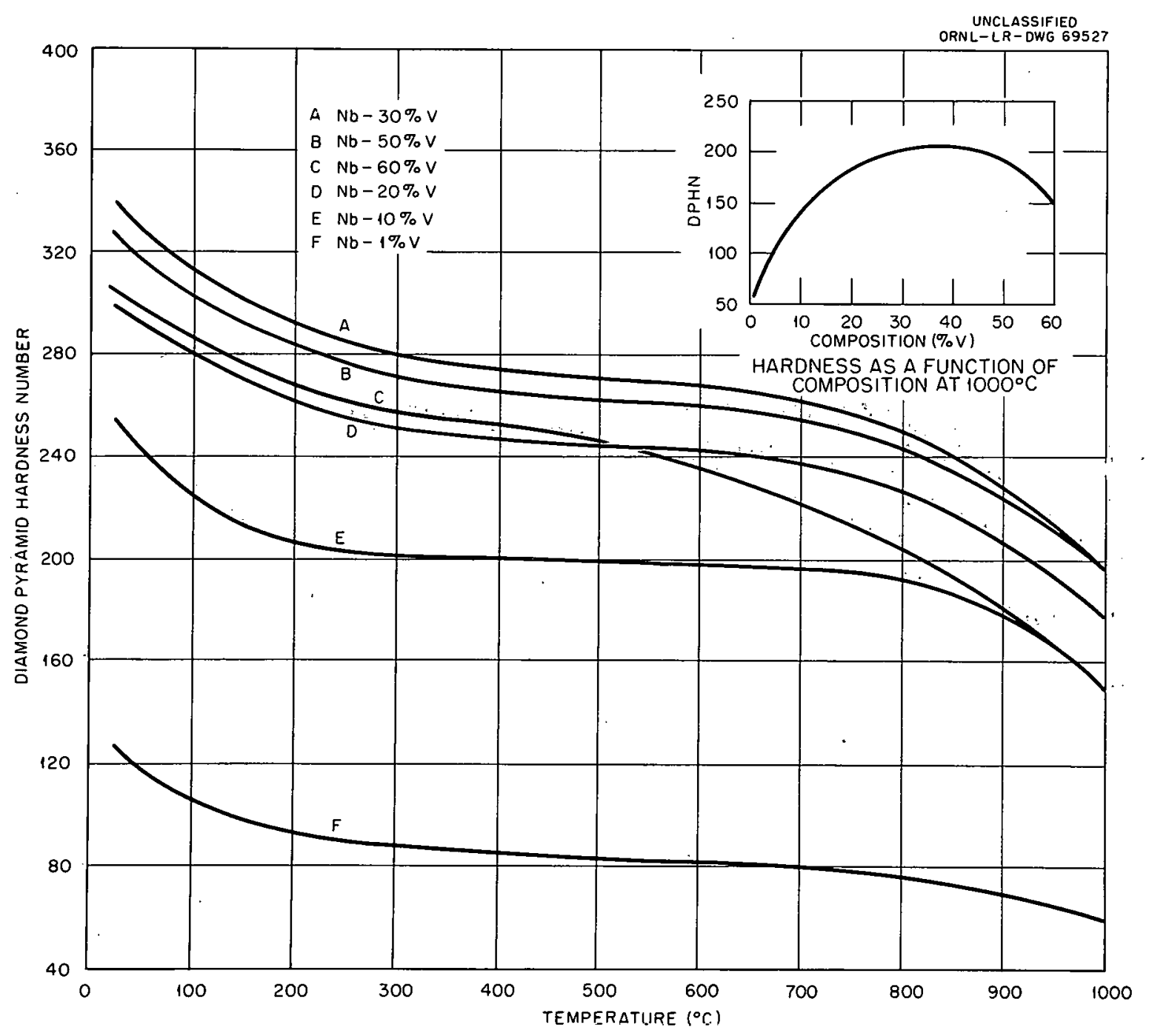

Fig. 14. Hardness of Niobium-Vanadium Alloys as a Function of Temperature. 2-kg load. 
UNCLASSIFIED

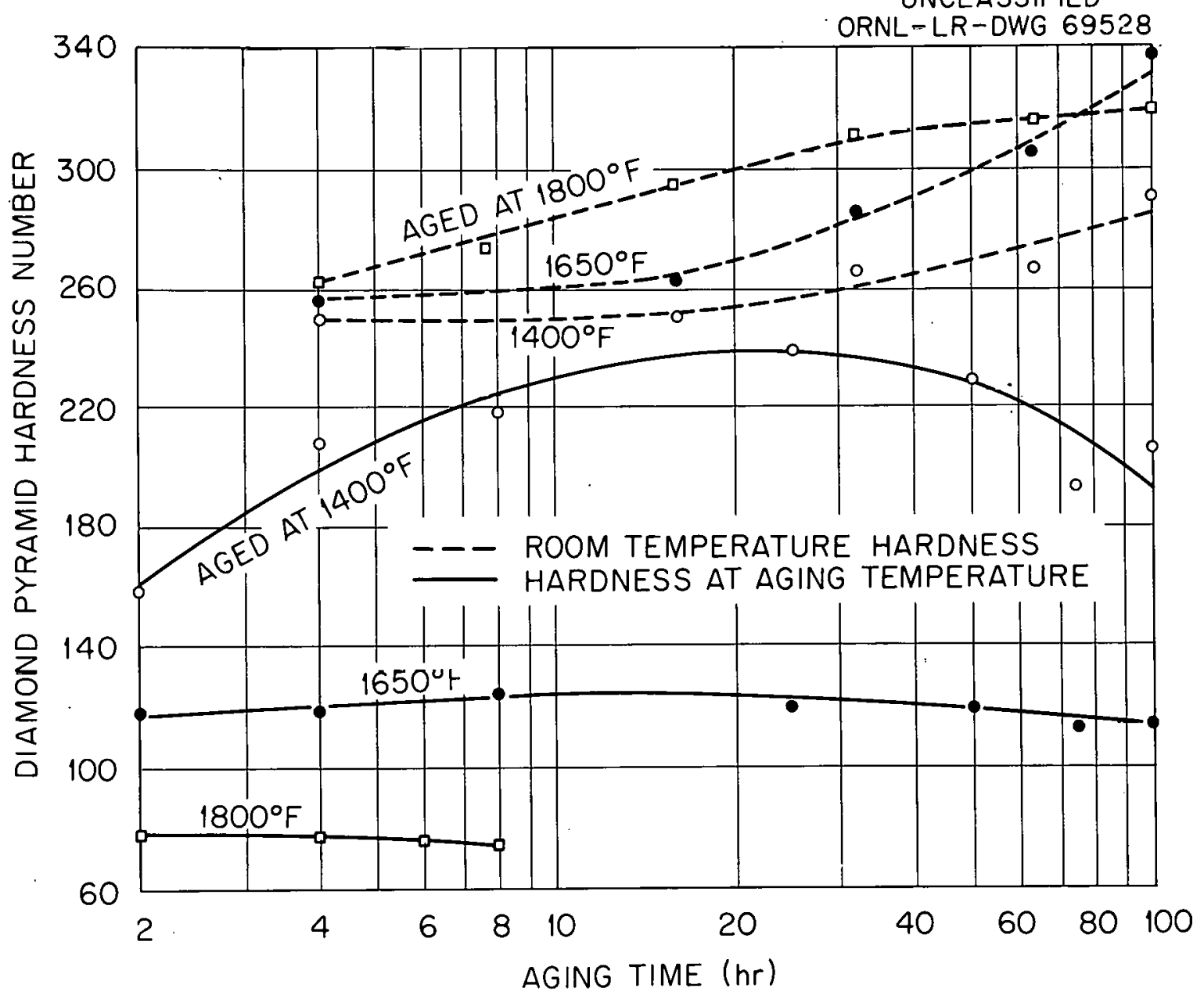

Fig. 15. Age Hardening of Haynes Alloy No. 25. 2-kg load. 
temperatures with the aid of the microindentation hardness tester. The specimens were heated isothermally and hardness impressions were made after various time intervals up to $100 \mathrm{hr}$. The results of these determinations are represented by solid lines in Fig. 15.

Comparison of the two sets of curves shows, as expected, that the hardness values determined at the aging temperatures are lower than the room-temperature hardness of the quenched specimens. The conventional room-temperature hardness curves show that, up to $75-\mathrm{hr}$ aging, the $1800^{\circ} \mathrm{F}$ sample is the hardest, followed by the 1650 and $1400^{\circ} \mathrm{F}$ samples; however, hardness measurements made at the elevated temperatures show the reverse order. An extremely important feature of hot hardness measurements of this alloy is the evidence of overaging or a hardness decrease at all of the aging temperatures.

It must be pointed out that there is little correlation between the two hardness testing procedures; however, hot hardness testing of an age-hardenable alloy at temperatures simulating the conditions of practical utilizations appears to be more applicable than the conventional hardness determinations made after quenching the sample to room temperature. In addition, there is a considerable saving of time in processing the smaller number of samples. for age-hardening determinations with the elevated-temperature hardness testing method.

\section{CONCLUSIONS}

The elevated-temperature hardness testing equipment described in this report has been in operation at ORNL for the past two years, and used mainly as a screening tool in the development of alloys with desirable high-temperature properties. The majority of the tests was performed on the microindentation hardness tester which is more sensitive and accurate than the Rockwell tester. The successful operation of the elevated-temperature microindentation hardness tester is primarily related to the simplicity in design of the dead-loading indenter system and to the ability to control the duration of fully applied loads. 
The maximum testing temperature with the present equipment is $1000^{\circ} \mathrm{C}$. The basic design of the microindentation hardness tester is also adaptable for higher testing temperatures; the maximum temperature, however, is limited by the presently available high-temperature indenter materials.

\section{ACKNOWLEDGMENTS}

The authors wish to express their appreciation to E. S. Cantrell and D. L. Holcomb for their major contributions in the design and construction of the microindentation hardness tester. Gratitude is also extended to T. J. Henson for his assistance in hot hardness determinations. 
THIS PAGE WAS INTENTIONALLY
LEFT BLANK 


$$
\begin{gathered}
\text { ORNL-3448 } \\
\text { UC-25 - Metals, Ceramics, and Materials } \\
\text { TID-4500 (20th ed.) }
\end{gathered}
$$

\section{INIERNAL DISTRIBUTIION}

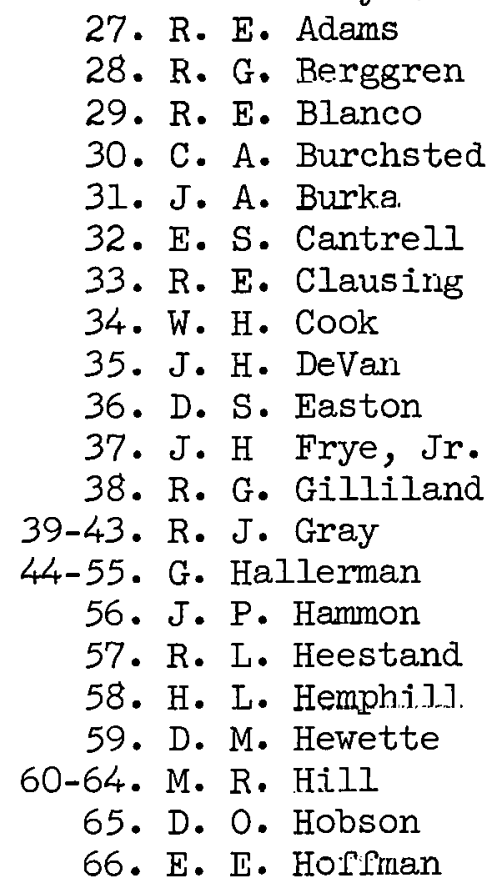

27. R. E. Adams

28. R. G. Berggren

29. R. E. Blanco

30. C. A. Burchsted

31. J. A. Burka.

32. E. S. CantrelI

33. R. E. Clausing

34. W. H. Cook

35. J. H. DeVan

36. D. S. Easton

37. J. H Frye, Jr.

38. R. G. Gilliland

39-43. R. J. Gray

44-55. G. Hallerman

56. J. P. Hammon

57. R. L. Heestand

58. H. L. Hemphi1.1.

59. D. M. Hewette

60-64. M. R. Hill

65. D. O. Hobson

66. E. E. Horfman

1-2. Central Research Iibrary

3. Reactor Division Library

4-5. ORNL - Y-12 Technical Library Document Reference Section

6-25. Laboratory Records Department

26. Laboratory Records, ORNL R.C.
67. T. M. Kegley, Jr.

68. C. E. Larson

69. C. F. Jieitten

70. H. G. MacPherson

71. M. M. Martin

72. H. E. McCoy

73. D. L. McElroy

74. E. C. Miller

75. C. S. Morgan

76. J. F. Murdock

77. S. Peterson

78. M. L. Picklesjmer

79. S. A. Rabin

80. T. K. Roche

81. L. D. Schaffer

82. M. J. Skinner

83. G. M. Slaughter

84. W. J. Stelzman

85. R. L. Stephenson

86. J. O. Stiegler

87. J. A. Swartout

88. W. C. Thurber

89. A. M. Weinberg

90. A. A. Burr (consultant)

91. J. R. Johnson (consultant)

92. C. S. Smith (consultant)

93. R. Smoluchowski (consultant)

\section{EXTERNAL DISTRIBUTION}

94-95. Dav1d F. Cope, Oak Ridge Operations Office

96. D. E. Baker, GE Hanford

97. Ersel Evans, GE Hanford

98. J. L. Gregg, Cornell University

99. J. Simmons, AEC, Washington

100. Lawrence M. Slifkin, University of North Carolina

101. E. E. Stansbury, University of Tennessee

102. Donald K. Stevens, AEC, Washington

103. Research and Development Division, AEC, ORO

104-607. Given distribution as shown in TID-4500 (20th ed.) under Metals, Ceramics, and Materials category 